\title{
Vascular plant occurrences in grasslands of Central Forest Nature Reserve (Russia): a dataset
}

\author{
Oxana V. Cherednichenko ${ }^{\ddagger}$, Tatiana Gavrilova ${ }^{\ddagger}$ \\ $\ddagger$ Lomonosov Moscow State University, Moscow, Russia
}

Corresponding author: Oxana V. Cherednichenko (gentiana07@yandex.ru)

Academic editor: Alexey P. Seregin

Received: 20 Oct 2021 | Accepted: 05 Dec 2021 | Published: 10 Dec 2021

Citation: Cherednichenko OV, Gavrilova T (2021) Vascular plant occurrences in grasslands of Central Forest Nature Reserve (Russia): a dataset. Biodiversity Data Journal 9: e76806. https://doi.org/10.3897/BDJ.9.e76806

\begin{abstract}
Background

Here we present the sampling event dataset that contributes to studying the flora of grasslands in Central Forest State Nature Biosphere Reserve (part of the UNESCO World Network of Biosphere Reserves), Tver Oblast, Russia. The Reserve is located in the SW part of the Valdai Upland within the main Caspian-Baltic watershed of the Russian plain (Latitude: $56^{\circ} 26^{\prime}-56^{\circ} 39^{\prime} \mathrm{N}$, Longitude: $32^{\circ} 29^{\prime}-33^{\circ} 01^{\prime} \mathrm{E}$ ). The territory of Central Forest Reserve belongs to the subzone of subtaiga.
\end{abstract}

\section{New information}

The dataset includes the occurrences of vascular plant species in four types of grasslands from 209 vegetation plots (8,506 associated occurrences), collected in 2013-2014. The dataset described in this paper has never been published before.

As the grasslands in Central Forest State Nature Biosphere Reserve are relatively unstudied, we are providing a new comprehensive dataset on the vascular plant species occurrences in the grasslands of the Reserve. The dataset contains representative information on floristic composition of plant communities in localities with assigned GPS coordinates. As the vegetation of the Reserve is typical of the subtaiga subzone, the 
results of analysing this dataset can be useful for grassland management in the whole subtaiga subzone.

During this study, we found one vascular plant species included in the Red Data Book of the Russian Federation, three species from the Red Data Book of Tver Oblast, as well as 10 alien vascular plant species for the Reserve. These data, especially, the occurrences of protected and alien species, contribute to our knowledge of species composition of the grasslands of the Reserve.

\section{Keywords}

Russia, Tver Oblast, grasslands, flora, occurrence, dataset, Darwin Core

\section{Introduction}

We provide a dataset on the occurrences of vascular plants in the grasslands of Tsentral' nolesnoy Biosphere Reserve, further referred to as "Central Forest State Nature Biosphere Reserve", as it is mentioned in GBIF. The Central Forest State Nature Biosphere Reserve (CFR) is located in the SW part of the Valdai Upland within the main Caspian-Baltic watershed of the Russian plain (Latitude: $56^{\circ} 26^{\prime}-56^{\circ} 39^{\prime} \mathrm{N}$, Longitude: $32^{\circ} 29^{\prime}-33^{\circ} 01^{\prime}$ E). CFR was established in 1931, then it was closed in 1951 and re-established in 1960. The Reserve has been a part of the UNESCO World Network of Biosphere Reserves since 1985. According to the classification of the International Union for Conservation of Nature (IUCN), the Reserve belongs to the la category: Strict Nature Reserve (State Nature Reserve). Like all biosphere reserves, CFR has zones free of human interference (core area), buffer zones commonly used for activities compatible with sound ecological practices, such as education and research and a transition area where restricted agricultural use is allowed. The studied grasslands are situated in the core and the transition area of the Reserve. The core area comprises 24,415 ha, the transition area 46,061 ha (Cadastral information on the Central Forest Reserve) (Fig. 1). The Reserve protects endangered species and ecosystems as a whole to maintain the biological diversity in its natural state; preserves and studies mixed broad-leaved coniferous old growth forests and raised bogs; carries out long-term environmental studies and environmental education.

The relief of the territory is mostly flat, with only low and generally gentle slopes of riverbanks and streams. The soils are sod-podzolic and gley-podzolic. The climate is humid continental (Minayeva and Shaposhnikov 1999). The mean annual rainfall for the period 1963-2014 is $760 \mathrm{~mm}$ (510 to $1050 \mathrm{~mm}$ in different years). The mean January temperature is $-8.6^{\circ} \mathrm{C}$ (the absolute minimum is $-39.4^{\circ} \mathrm{C}$ ) and the mean July temperature is $+16.9^{\circ} \mathrm{C}$ (the absolute maximum is $+36.5^{\circ} \mathrm{C}$ ) (Cherednichenko and Borodulina 2018).

Central Forest Reserve is situated in the subtaiga zone (Safronova et al. 2010). In the vegetation of the Reserve, forests prevail: spruce forests cover $47 \%$ of the whole area, 
secondary forests occupy $40 \%$. Boggy pine forests and both oligo- and mesotrophic mires occupy $9 \%$ and $4 \%$ of the area, respectively. Grasslands cover less than $1 \%$ of the Reserve's area (Kurayeva et al. 1999). The vegetation is typical of the taiga biome and, therefore, preserved in the Reserve as a reference.

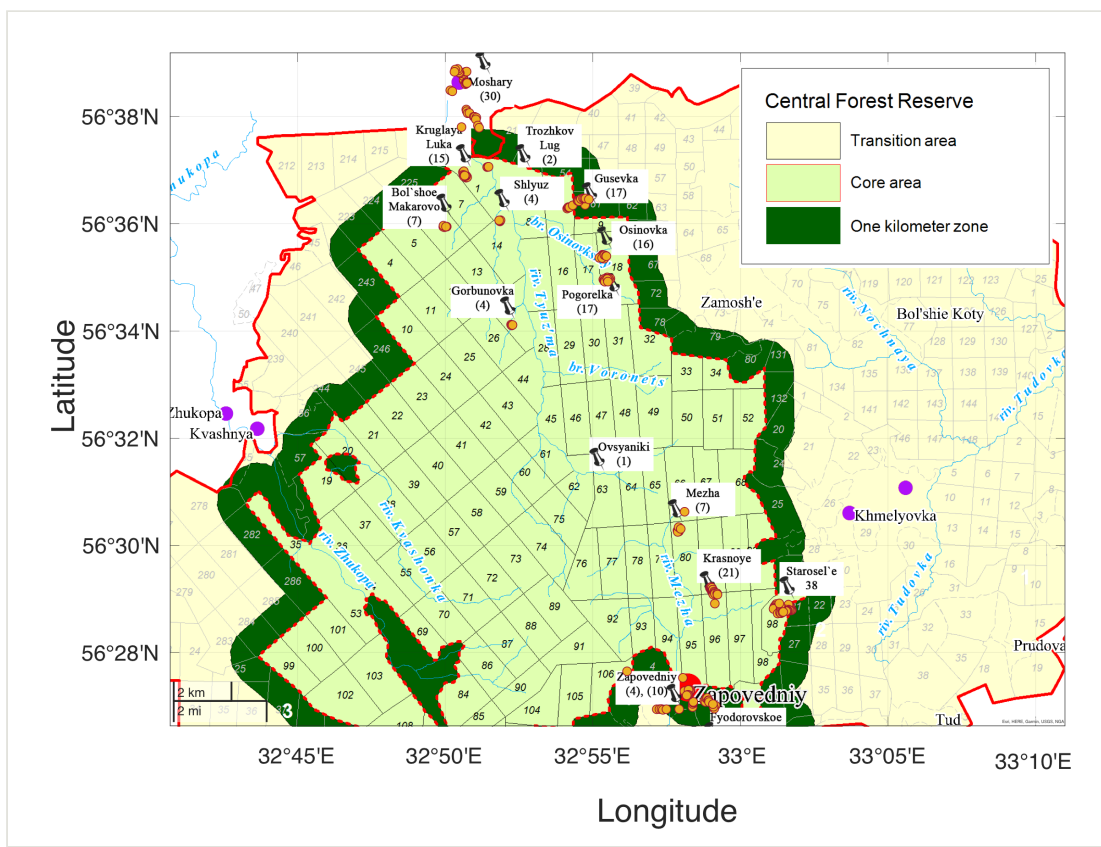

Figure 1. doi

Locations of vegetation plots sampled in 2013 and 2014 in the Reserve and its vicinity.

The present-day flora of CFR includes 592 species of vascular plants (Konechnaya 2012) including 43 Red-listed species from the Red Data Book of the Russian Federation (Bardunov and Novikov 2008) and the Red Data Book of Tver Oblast (Orlov and Sokolov 2016) (40 species).

The grasslands occupy just $1 \%$ of the Reserve's area, yet $40 \%$ of species of its vascular plant flora can be found there. In other words, although the grasslands occupy a relatively small area, they are floristically rich (Cherednichenko and Borodulina 2018).

The flora and phenology of the Central Forest Reserve were actively studied (Minayev and Konechnaya 1976, Konechnaya 2012, Shuyskaya 2018, Zorina et al. 2020), but the works describing the vegetation of the Reserve predominantly focused on the forests and the raised bogs (Karpov 1983, Kurayeva et al. 1999, Minaeva et al. 2007, Minaeva 2010, Korablev et al. 2018). Therefore, there are few publications concerning the grassland vegetation of the Reserve (Elumeeva et al. 2017, Cherednichenko and Borodulina 2018, Cherednichenko et al. 2021, Elumeeva et al. 2017Elumeeva et al. 2021). Only the paper of Cherednichenko and Borodulina (2018) focused on the diversity of grasslands in the Reserve. In this data paper, we describe the dataset providing the basis for identifying four 
grassland types in the Reserve (managed mesic, abandoned mesic, subruderal mesic and wet grasslands); this dataset is published for the first time. The other three papers focused on functional traits of leaves (Elumeeva et al. 2017) and phytomass of two grassland types (managed mesic and abandoned mesic grasslands) (Cherednichenko et al. 2021), as well as on the decomposition rate of standard material in grassland soils (Tea bag index) (Elumeeva et al. 2021).

The present data include the sample plots made in 2013-2014 and, based on which, four types of grasslands were identified (Cherednichenko and Borodulina 2018) (Table 1). Three of these types are mesic grasslands (manaded, abandoned and subruderal) and one type belongs to wet grasslands. The sites are ecologically and physiognomically different due to their management and moisture regime. Therefore, the variability between the study sites is considerable. The sampled vegetation data will provide insight into the biodiversity and current state of the grasslands in CFR and its transition area. The dataset includes information on the occurrence of the threatened and alien species of CFR.

Table 1.

Grassland types distinguished in the dataset and their distribution amongst the studied sites.

\begin{tabular}{|l|l|l|}
\hline Grassland type & Number of sample plots & Number of sites \\
\hline Managed mesic grasslands & 51 & 3 \\
\hline Abandoned mesic grasslands & 79 & 10 \\
\hline Wet grasslands & 24 & 6 \\
\hline Subruderal mesic grasslands & 55 & 10 \\
\hline
\end{tabular}

\section{General description}

Purpose: The present article is aimed at digitally representing and making available the data on the occurrences of vascular plants in the grasslands of CFR. This study is important because it was carried out in the territory where all kinds of economic activities are prohibited. As a result, the natural ecological succession has not been interrupted since 1960 and, in a number of cases, since the 1980s. So, the grasslands are being overgrown with forest, their area is decreasing and they may soon disappear completely from the territory of the Reserve and no information about them will remain. Thus, the data collected in 2013-2014 can be used in future studies to assess the characteristics of ecological succession and the restoration of natural mixed coniferous - broad-leaved forests in the Reserve area. Furthermore, these data can be used for monitoring, ecological restoration and appropriate management of the grasslands in the Reserve.

\section{Sampling methods}

Study extent: Grasslands (meadows, pastures and ruderal communities) in CFR exist under the protection regime in the Reserve's core area (Fig. 1) and under agricultural use 
in adjacent territories. The grasslands of the core area have not been used due to the protection regime since the early 1960s and several sites since the 1980s; thus, most of the grasslands were abandoned 30-60 years ago. In the core area of CFR, there are only small patches of grasslands in the places of former settlements (villages, farmsteads, forest huts). Having been abandoned for a long time, some communities still resemble grass-forb grasslands, while others have completely changed and turned into shrub or forest vegetation. Large areas are covered with subruderal tall-herb stands dominated by forbs (Anthriscus sylvestris (L.) Hoffm., Chamaenerion angustifolium (L.) Scop., Urtica dioica $\mathrm{L}$. etc.). These communities can be found in the places of abandoned housing in former villages, as well as at the sites of wild boar digging (Cherednichenko and Borodulina 2018).

The grasslands in the core area of the Reserve are not managed anymore and, therefore, are being overgrown with forest. To date, the area of grasslands has significantly decreased: in 2017, the area of the grasslands per se was estimated as $0.02 \%$ of the total Reserve area, while forest glades and wastelands covered with herbaceous vegetation occupied $0.5 \%$ of the total Reserve area (Cadastral information on the Central Forest $\underline{\text { Reserve)}}$. For example, the area of the Krasnoe site covered with grassland vegetation has decreased almost 5 times over the past 35 years (from 26.6 ha to 5.54 ha) (Cherednichenko et al. 2021).

Grasslands occupy large areas around villages in the transition area and in the one kilometre buffer zone. At present, the vast majority of these grasslands are abandoned, while only limited areas of meadows and pastures are managed (irregular mowing and low intensity grazing). The managed grasslands were studied in the vicinity of the CFR headquarters and around inhabited villages, situated in both the buffer zone and the transition area of the Reserve (Cherednichenko and Borodulina 2018).

Sampling description: This dataset includes 209 sample plots of continental grasslands made in 2013 and 2014. In 2013, we sampled 88 plots at six sites in the south of the Reserve (Bol'shoe Fyodorovskoe, Mezha, Krasnoye, Ovsyaniki, Starosel'e, Zapovedniy). In 2014, we sampled 121 plots: 111 ones at nine sites in the north (Bol'shoe Makarovo, Gorbunovka, Gusevka, Kruglaya Luka, Moshary, Osinovka, Pogorelka, Shlyuz, Trozhkov Lug) and 10 sites in the south of the Reserve (Zapovedniy) (Fig. 1). The position of the centre of each vegetation plot was georeferenced using a Garmin GPS navigator in WGS84 datum. The dataset comprises most of the continental grasslands in the core area of CFR. However, we studied only a limited number of grassland sites in the transition zone of the Reserve due to its large area.

The size of each sample plot was $100 \mathrm{~m}^{2}$, which is considered appropriate for grassland vegetation (Mirkin and Naumova 2012). Plots of this size were used to sample grassland vegetation in a number of works (Chytrý and Otýpková 2003). According to Chytrý and Otýpková (2003), $16 \mathrm{~m}^{2}$ plots should be used as standard to sample most types of herbaceous vegetation. As we used larger sample plots $\left(100 \mathrm{~m}^{2}\right)$, we consider our vegetation samples for each plot complete in terms of their species composition. Within the sample plots, we collected the data on species composition. 
Our data represent almost all grassland types in the Reserve (Table 1) according to their physiognomy and land use type. The sample plots were compiled in visually homogenous areas of vegetation along the visible gradients of the relief, as a rule from the edge to the centre of the grassland to cover the entire diversity of plant communities of each site.

We would like to highlight that the presence of two particular groups of species, namely the Red-listed species and the alien (including invasive) ones, in the dataset is closely connected with the type of the studied grasslands and their management. The alien and invasive species are provided according to Vinogradova et al. (2011), the Red-listed species follow the Red Data book of the Russian Federation (plants and fungi) (Bardunov and Novikov 2008) and the Red Data Book of Tver Oblast (Orlov and Sokolov 2016).

Quality control: The plant species were predominantly identified in the field; when it was not possible to unambiguously identify the specimen, it was herborised for further identification at the laboratory. Most of the species were identified using the keys (Tsvelev 2000, Maevsky 2014) by Oxana Cherednichenko. In difficult cases of species, the identification was confirmed by Alexey Seregin, sedges were confirmed or identified by Yuriy Alekseev and Mikhail Kozhin and specimens of the genus Pilosella were identified by Alexander Sennikov. The collected specimens are deposited at Moscow University Herbarium (MW) and are publicly available in Moscow Digital Herbarium. In 2013, 33 herbarium specimens were collected, in 2014 - 230 herbarium specimens.

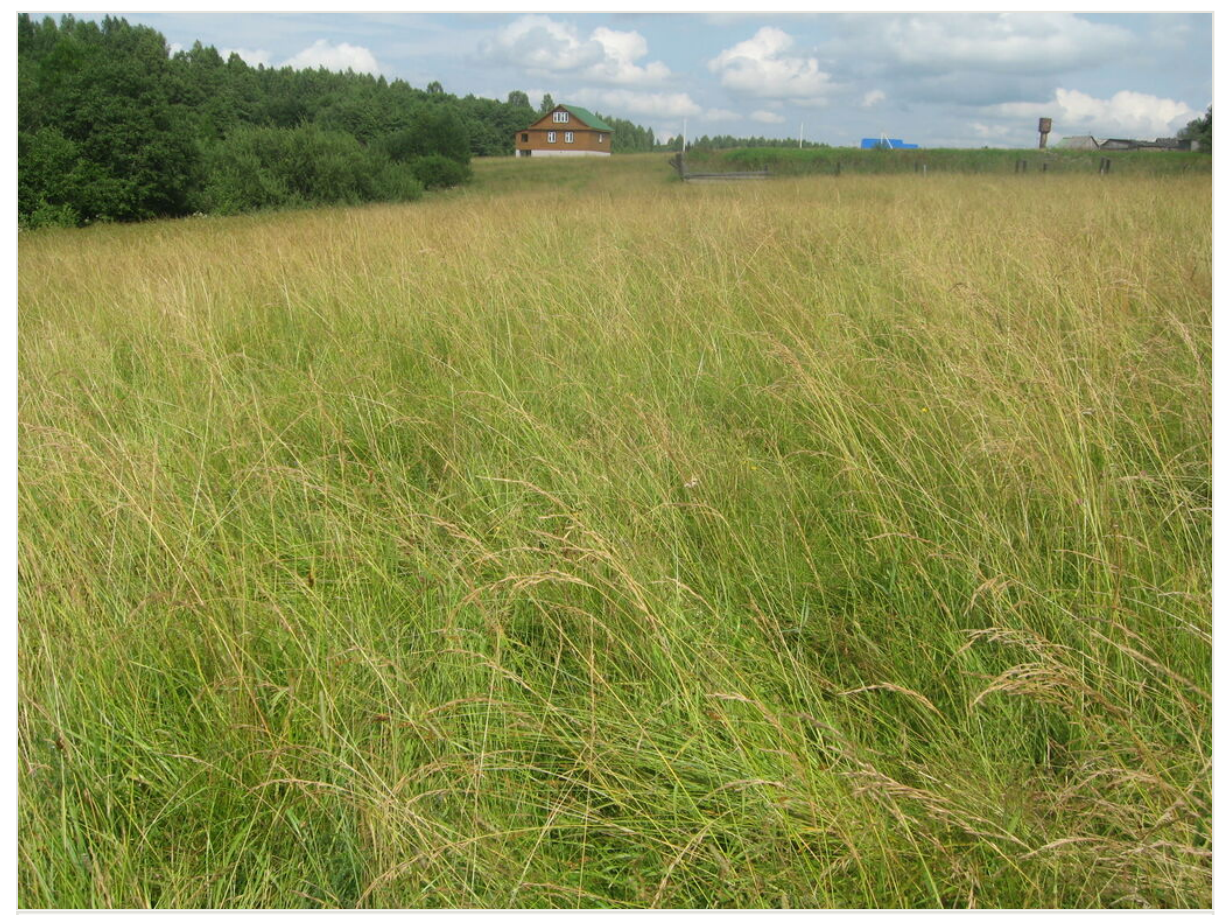

Figure 2. doi

Managed mesic grassland, Bol'shoe Fyodorovskoe site, plot MW-C054 (Latitude 56.45102964 Longitude 32.97338868). Dominant species: Carex leporina L. and Festuca pratensis Huds. 
The plant scientific names in the dataset were checked against the database of

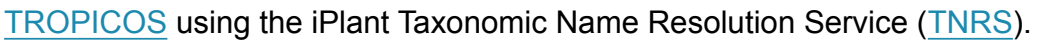

Step description: As a habitat characteristic, we used the classification of grassland types described in Cherednichenko and Borodulina (2018). The grassland types were determined using cluster analysis, indicator species analysis and phytoindication assessment. Thus, we distinguish four types of grasslands: managed mesic (Fig. 2), abandoned mesic (Fig. 3), wet (Fig. 4) and subruderal mesic grasslands (Fig. 5), that are presented in Table 1; they are also available in the GBIF dataset (Cherednichenko 2021).

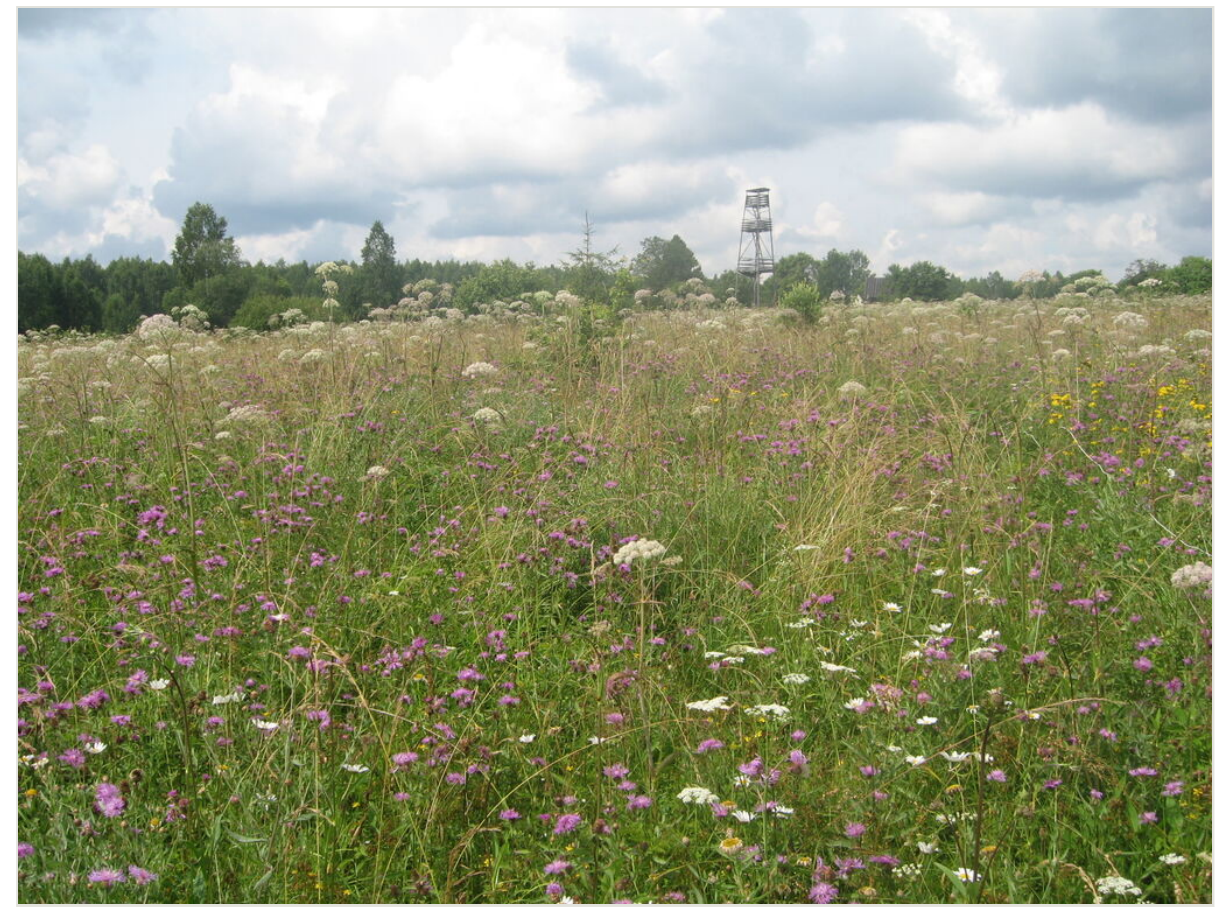

Figure 3. doi

Abandoned mesic grassland, Starosel'e site, plot MW-C05 (Latitude 56.47998819 Longitude 33.02556393). Dominant species: Angelica sylvestris L., Centaurea phrygia L., Festuca pratensis Huds., Leucanthemum vulgare Lam. and Pimpinella saxifraga L.

These four grassland types differ in management, floristic composition and ecological conditions, as well as in the proportion of coenotic and functional groups (including forbs, graminoids and woody species). Managed mesic grasslands (Fig. 2) are communities with the dominance of grasses and forbs under moderate grazing and irregular mowing. Their indicator species are Cynosurus cristatus L., Leontodon autumnalis L., Plantago major L., Potentilla anserina L. and Taraxacum officinale Wigg. Abandoned mesic grasslands (Fig. 3) were mown or grazed in the past and they still resemble typical meadows with the dominance of forbs and grasses. Their indicator species are Hieracium umbellatum L., Potentilla erecta (L.) Raeusch., Rumex acetosa L., Trollius europaeus L. and Viola canina 
L. Wet grasslands are tall-herb meadowsweet communities (Fig. 4), forming in small relief depressions and along temporary streams, probably in the places of abandoned hayfields. Their indicator species are Cirsium palustre (L.) Scop., Crepis paludosa (L.) Moench, Filipendula ulmaria (L.) Maxim., Galium palustre L. and Viola palustris L. Subruderal mesic grasslands (Fig. 5) are not currently managed and are totally covered with ruderal and nitrophilous species. Their indicator and dominant species are Anthriscus sylvestris (L.) Hoffm., Chamaenerion angustifolium (L.) Scop., Cirsium arvense (L.) Scop., Dactylis glomerata L. and Urtica dioica L.

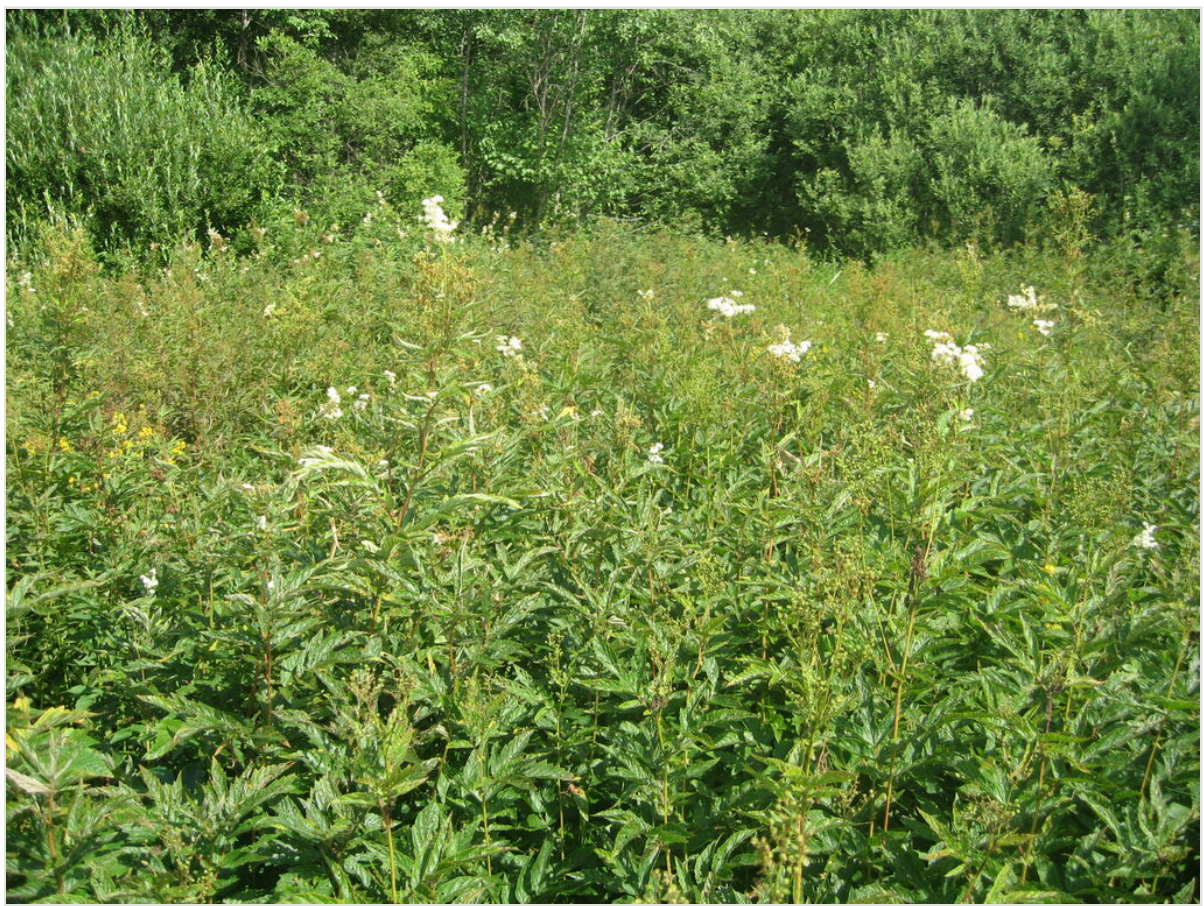

Figure 4. doi

Wet grassland, site: Bol'shoe Fyodorovskoe, plot MW-C042 (Latitude 56.45129258 Longitude 32.97338742). Dominant species: Filipendula ulmaria (L.) Maxim. and Lysimachia vulgaris L.

Table 1 shows that abandoned and subruderal mesic grasslands were the most widespread in the study area, while wet grasslands, associated with specific, more humid conditions, were less frequent. Managed mesic grasslands were less widespread, since there are few inhabited villages in the transition area of the Reserve.

\section{Geographic coverage}

Description: Tver Oblast, Russia

Coordinates: 56.44882 and 56.64804 Latitude; 32.83221 and 33.02906 Longitude. 


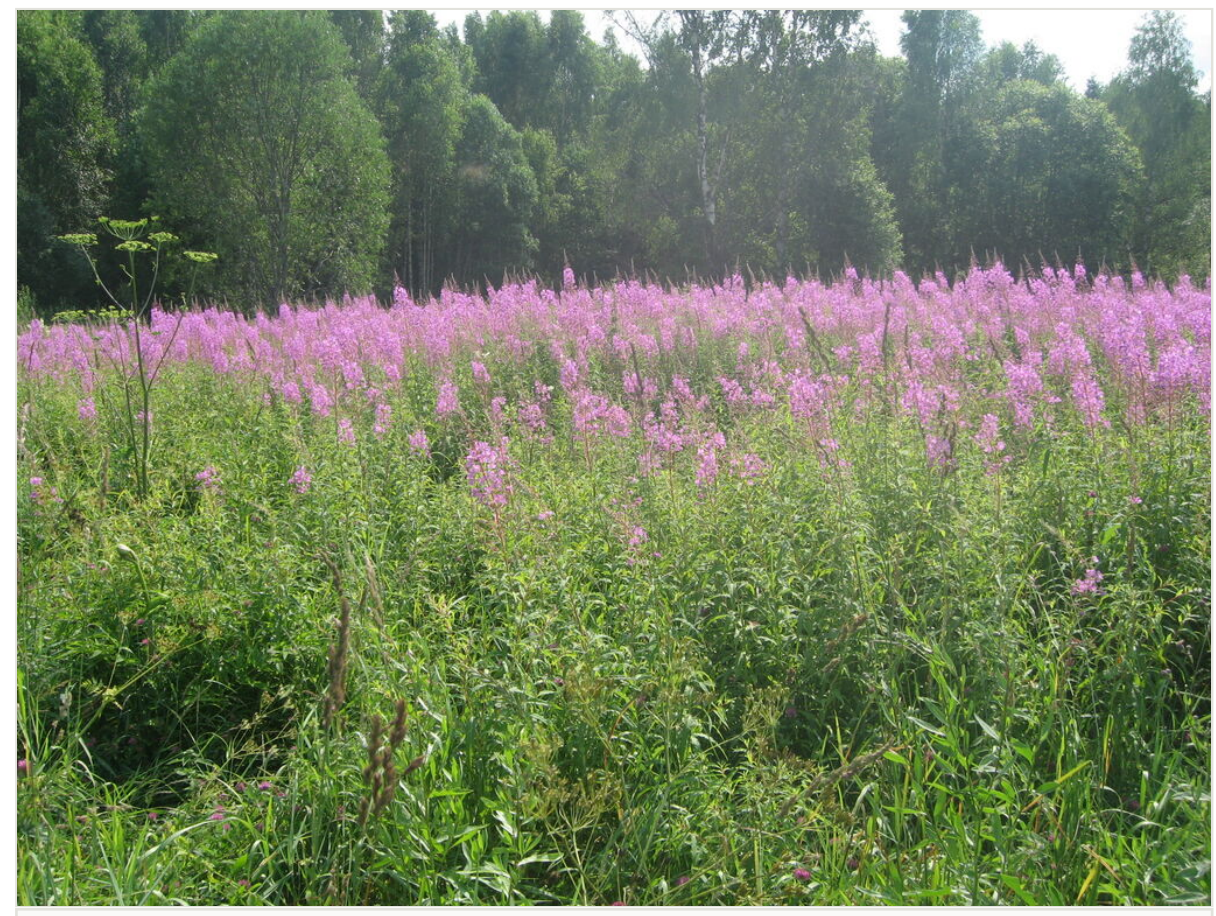

Figure 5. doi

Subruderal mesic grassland, Krasnoe site, plot MW-C015 (Latitude 56.48472472 Longitude 32.98469234). Dominant species: Anthriscus sylvestris (L.) Hoffm., Chamaenerion angustifolium (L.) Scop., Dactylis glomerata L. and Heracleum sibiricum L.

Although the community is dominated by Chamaenerion angustifolium (L.) Scop., this is not a clearing, this grassland had formerly been mown and was abandoned 30 years ago. The dominance of Chamaenerion angustifolium (L.) Scop. may be connected with wild boar digging, as wild boars completely destroy the vegetation cover of this site once in a few years. This is a typical appearance of abandoned vegetation in the Reserve, not only at Krasnoe site, but also at a number of other sites.

\section{Taxonomic coverage}

Description: The dataset includes 261 unique scientific names of vascular plants (260 taxa were identified to species ranks and one taxon to aggregate rank only - Alchemilla vulgaris agg.). General taxonomic coverage is one phylum, four classes, 48 families, 154 genera and 261 species of vascular plants.

Thus, the dataset comprises $44.1 \%$ of the whole Reserve's flora, which consists of 592 species (Konechnaya 2012). Furthermore, the flora of the studied grasslands makes up $16.5 \%$ of the Tver Oblast checklist (1579 species) (Notov 2005).

There are 190 species typical of the grasslands per se in the list compiled by Konechnaya (2012) (the total number of species in this list is 529), while our dataset contains 261 
species. A total of 141 species were included both in the list provided by Konechnaya (2012) and in our dataset, the rest of the species from our dataset are listed in Konechnaya (2012) as characteristic of forests and forest edges, as well as of ruderal and wet habitats. Five species that we recorded, namely Hieracium scandinavicum Dahlst., Potentilla intermedia L., Swida alba (L.) Opiz, Triticum aestivum L. and Vicia villosa Roth, are absent in the list compiled by Konechnaya (2012), all these species having low occurrence in the transition zone of the Reserve.

Revealing the complete grassland flora of the Reserve was beyond the scope of our study. The dataset we published is based on sampling the vegetation of particular grassland sites in the Reserve. Therefore, we detected less species than had previously been recorded (Konechnaya 2012) for the grasslands of the Reserve. Nevertheless, we provide the geographical coordinates for all the grassland species that we observed.

During our grassland studies, we found one vascular plant species included in the Red Data Book of the Russian Federation (Bardunov and Novikov 2008): Dactylorhiza baltica (Klinge) Nevski and three Red-listed species from the Red Data Book of Tver Oblast (Orlov and Sokolov 2016): Coeloglossum viride (L.) C. Hartm., Gymnadenia conopsea (L.) R. Br. and Salix phylicifolia L.

Ten alien species were recorded in the dataset, including eight invasive plants: Conyza canadensis (L.) Cronq., Epilobium ciliatum Rafin., Festuca arundinacea Schreb., Juncus tenuis Willd., Lepidotheca suaveolens (Pursh) Nutt., Lolium perenne L., Malus domestica Borkh. and Petasites hybridus (L.) Gaertn., B. Mey. \& Scherb. (according to the list of Vinogradova et al. (2011)); and two cultivated species: Swida alba (L.) Opiz and Triticum aestivum $\mathrm{L}$.

Vinogradova et al. (2011) list 100 invasive species for Tver Oblast and 39 species for Nelidovsky District, amongst them, species with low activity prevail. In general, the activity of the invasive flora in Nelidovsky District is low (Vinogradova et al. 2011). Invasive species were seldom observed at the study sites, occurring mostly in managed mesic grasslands and were completely absent in wet ones (Cherednichenko and Borodulina 2018). Juncus tenuis Willd. (35\%) was the most widespread in managed mesic grasslands and Malus domestica Borkh. (32\%) in abandoned mesic grasslands. The list of Vinogradova et al. (2011) does not include two alien species cultivated in the transition area of the Reserve which were observed at the study sites (Triticum aestivum L. and Swida alba (L.) Opiz).

Taxa included:

\begin{tabular}{|l|l|}
\hline Rank & Scientific Name \\
\hline kingdom & Plantae \\
\hline phylum & Tracheophyta \\
\hline class & Liliopsida \\
\hline class & Magnoliopsida \\
\hline
\end{tabular}




\begin{tabular}{|c|c|}
\hline class & Pinopsida \\
\hline class & Polypodiopsida \\
\hline family & Amaranthaceae \\
\hline family & Apiaceae \\
\hline family & Asteraceae \\
\hline family & Athyriaceae \\
\hline family & Betulaceae \\
\hline family & Boraginaceae \\
\hline family & Brassicaceae \\
\hline family & Campanulaceae \\
\hline family & Caprifoliaceae \\
\hline family & Caryophyllaceae \\
\hline family & Convolvulaceae \\
\hline family & Cornaceae \\
\hline family & Crassulaceae \\
\hline family & Cupressaceae \\
\hline family & Cyperaceae \\
\hline family & Dryopteridaceae \\
\hline family & Equisetaceae \\
\hline family & Euphorbiaceae \\
\hline family & Fabaceae \\
\hline family & Geraniaceae \\
\hline family & Hypericaceae \\
\hline family & Juncaceae \\
\hline family & Lamiaceae \\
\hline family & Linaceae \\
\hline family & Malvaceae \\
\hline family & Onagraceae \\
\hline family & Onocleaceae \\
\hline family & Ophioglossaceae \\
\hline family & Orchidaceae \\
\hline
\end{tabular}




\begin{tabular}{|c|c|}
\hline family & Orobanchaceae \\
\hline family & Pinaceae \\
\hline family & Plantaginaceae \\
\hline family & Poaceae \\
\hline family & Polemoniaceae \\
\hline family & Polygalaceae \\
\hline family & Polygonaceae \\
\hline family & Primulaceae \\
\hline family & Ranunculaceae \\
\hline family & Rhamnaceae \\
\hline family & Rosaceae \\
\hline family & Rubiaceae \\
\hline family & Salicaceae \\
\hline family & Saxifragaceae \\
\hline family & Scrophulariaceae \\
\hline family & Solanaceae \\
\hline family & Urticaceae \\
\hline family & Viburnaceae \\
\hline family & Violaceae \\
\hline
\end{tabular}

\section{Temporal coverage}

Notes: Data range: 08.07.2013 - 18.07.2013; 05.07.2014 - 21.07.2014.

\section{Usage licence}

Usage licence: Creative Commons Public Domain Waiver (CC-Zero)

\section{Data resources}

Data package title: Vascular plants of grasslands in Central Forest Nature Reserve (Tver Oblast, Russia).

Resource link: https://doi.org/10.15468/ufbxsn 
Alternative identifiers: https://www.gbif.org/dataset/bc6d4ac6-a710-456e-b75f-8dbaf $\underline{540 \text { eab3 }}$

\section{Number of data sets: 1}

Data set name: Vascular plants of grasslands in Central Forest Nature Reserve (Tver Oblast, Russia).

\begin{tabular}{|c|c|}
\hline Column label & Column description \\
\hline occurrencelD & $\begin{array}{l}\text { An identifier for the occurrence (unique). For example, "urn:Isid:biocol.org:col: } \\
\text { 15550:14:M102:3025". }\end{array}$ \\
\hline dcterms:type & The nature or genre of the resource. A constant ("Dataset"). \\
\hline dcterms:modified & $\begin{array}{l}\text { The most recent date-time on which the resource was changed. A constant } \\
\text { ("2021-10-12"). }\end{array}$ \\
\hline dcterms:language & A language of the resource. A constant ("en" = English). \\
\hline dcterms:license & $\begin{array}{l}\text { A legal document giving official permission to do something with the resource. A } \\
\text { constant (http://creativecommons.org/licenses/by/4.0/legalcode). }\end{array}$ \\
\hline dcterms:rightsHolder & $\begin{array}{l}\text { A person or organisation owning or managing rights over the resource. A constant } \\
\text { ("Moscow State University"). }\end{array}$ \\
\hline dcterms:accessRights & $\begin{array}{l}\text { Information about who can access the resource or an indication of its security } \\
\text { status. A constant ("Use under CC BY } 4.0 ") \text {. }\end{array}$ \\
\hline institutionID & $\begin{array}{l}\text { An identifier for the institution having custody of the object(s) or information } \\
\text { referred to in the record. A constant (http://grbio.org/institution/moscow-state- } \\
\text { university for the Moscow State University). }\end{array}$ \\
\hline collectionID & $\begin{array}{l}\text { An identifier for the collection or dataset from which the record was derived. A } \\
\text { constant ("urn:Isid:biocol.org:col: } 15550 " \text { for the Moscow University Herbarium). }\end{array}$ \\
\hline datasetID & $\begin{array}{l}\text { An identifier for the set of data. May be a global unique identifier or an identifier } \\
\text { specific to a collection or institution. A constant ("urn:Isid:biocol.org:col:15550:15"). }\end{array}$ \\
\hline institutionCode & $\begin{array}{l}\text { The name (or acronym) in use by the institution having custody of the object(s) or } \\
\text { information referred to in the record. A constant ("Moscow State University"). }\end{array}$ \\
\hline datasetName & $\begin{array}{l}\text { The name identifying the dataset from which the record was derived. A constant } \\
\text { ("Vascular plants of grasslands in Central Forest Nature Reserve (Tver Oblast, } \\
\text { Russia)"). }\end{array}$ \\
\hline ownerInstitutionCode & $\begin{array}{l}\text { The name (or acronym) in use by the institution having ownership of the object(s) } \\
\text { or information referred to in the record. A constant ("Moscow State University"). }\end{array}$ \\
\hline basisOfRecord & The specific nature of the data record. A constant ("HumanObservation"). \\
\hline informationWithheld & $\begin{array}{l}\text { Additional information that exists, but that has not been shared in the given record. } \\
\text { A constant ("Associated ecological data, voucher information, syntaxa, functional } \\
\text { traits, geomorphological features of plots, id of plots"). }\end{array}$ \\
\hline
\end{tabular}




\begin{tabular}{|c|c|}
\hline recordedBy & $\begin{array}{l}\text { A list (concatenated and separated) of names of people, groups or organisations } \\
\text { responsible for recording the original occurrence. A variable, for example "Oxana } \\
\text { V. Cherednichenko | Valentina P. Borodulina | Veronika V. Gorik". }\end{array}$ \\
\hline occurrenceStatus & $\begin{array}{l}\text { A statement about the presence or absence of a taxon at a location. A constant } \\
\text { ("present"). }\end{array}$ \\
\hline eventDate & $\begin{array}{l}\text { The date or interval during which an event occurred. For occurrences, this is the } \\
\text { date when the event was recorded. A variable. }\end{array}$ \\
\hline habitat & $\begin{array}{l}\text { A category or description of the habitat in which the Event occurred. For example, } \\
\text { "managed mesic meadows". }\end{array}$ \\
\hline higherGeography & $\begin{array}{l}\text { A list (concatenated and separated) of geographic names less specific than the } \\
\text { information captured in the locality term. A constant ("Europe | Russian Federation } \\
\text { | Tver Oblast"). }\end{array}$ \\
\hline continent & The name of the continent in which the location occurs. A constant ("Europe"). \\
\hline country & $\begin{array}{l}\text { The name of the country or major administrative unit in which the location occurs. } \\
\text { A constant ("Russian Federation"). }\end{array}$ \\
\hline countryCode & The standard code for the country in which the location occurs. A constant ("RU"). \\
\hline stateProvince & $\begin{array}{l}\text { The name of the next smaller administrative region than country (state, province, } \\
\text { canton, department, region etc.) in which the location occurs. A constant ("Tver } \\
\text { Oblast"). }\end{array}$ \\
\hline county & $\begin{array}{l}\text { The full, unabbreviated name of the next smaller administrative region than } \\
\text { stateProvince (county, shire, department etc.) in which the Location occurs. For } \\
\text { example, "Andreapol'skiy District". }\end{array}$ \\
\hline verbatimLocality & $\begin{array}{l}\text { The original textual description of the place. A variable with grid square index. For } \\
\text { example, "Pogorelka". }\end{array}$ \\
\hline decimalLatitude & $\begin{array}{l}\text { The geographic latitude (in decimal degrees, using the spatial reference system } \\
\text { given in geodeticDatum) of the geographic centre of a location. A variable. }\end{array}$ \\
\hline decimalLongitude & $\begin{array}{l}\text { The geographic longitude (in decimal degrees, using the spatial reference system } \\
\text { given in geodeticDatum) of the geographic centre of a location. A variable. }\end{array}$ \\
\hline geodeticDatum & $\begin{array}{l}\text { The ellipsoid, geodetic datum or spatial reference system (SRS) upon which the } \\
\text { geographic coordinates given in decimalLatitude and decimalLongitude are based. } \\
\text { A constant ("WGS84"). }\end{array}$ \\
\hline coordinateUncertaintyInMeters & $\begin{array}{l}\text { The horizontal distance (in metres) from the given decimalLatitude and } \\
\text { decimalLongitude describing the smallest circle containing the whole of the } \\
\text { location. A constant (" } 8 \text { "). }\end{array}$ \\
\hline coordinatePrecision & $\begin{array}{l}\text { A decimal representation of the precision of the coordinates given in the } \\
\text { decimalLatitude and decimalLongitude. A constant ("0,00001"). }\end{array}$ \\
\hline
\end{tabular}




\begin{tabular}{|c|c|}
\hline georeferencedBy & $\begin{array}{l}\text { A list (concatenated and separated) of names of people, groups or organisations } \\
\text { who determined the georeference (spatial representation) of the location. For } \\
\text { example, "Oxana V. Cherednichenko | Valentina P. Borodulina | Veronika V. Gorik". }\end{array}$ \\
\hline georeferencedDate & The date on which the Location was georeferenced. A variable. \\
\hline georeferenceSources & $\begin{array}{l}\text { A list (concatenated and separated) of maps, gazetteers or other resources used } \\
\text { to georeference the Location, described specifically enough to allow anyone in the } \\
\text { future to use the same resources. A constant ("field GPS data"). }\end{array}$ \\
\hline scientificName & $\begin{array}{l}\text { The full scientific name, with authorship and date information, if known. A variable, } \\
\text { for example, "Achillea millefolium L.". }\end{array}$ \\
\hline kingdom & $\begin{array}{l}\text { The full scientific name of the kingdom in which the taxon is classified. A constant } \\
\text { ("Plantae"). }\end{array}$ \\
\hline phylum & $\begin{array}{l}\text { The full scientific name of the phylum or division in which the taxon is classified. A } \\
\text { constant ("Tracheophyta"). }\end{array}$ \\
\hline family & $\begin{array}{l}\text { The full scientific name of the family in which the taxon is classified. For example, } \\
\text { "Asteraceae". }\end{array}$ \\
\hline genus & $\begin{array}{l}\text { The full scientific name of the genus in which the taxon is classified. For example, " } \\
\text { Achillea". }\end{array}$ \\
\hline SpecificEpithet & $\begin{array}{l}\text { The name of the first or species epithet of the scientificName. For example, " } \\
\text { millefolium". }\end{array}$ \\
\hline taxonRank & $\begin{array}{l}\text { The taxonomic rank of the most specific name in the scientificName. A constant } \\
\text { ("Species"). }\end{array}$ \\
\hline scientificNameAuthorship & $\begin{array}{l}\text { The authorship information for the scientificName formatted according to the } \\
\text { conventions of the applicable nomenclaturalCode. For example, "L.". }\end{array}$ \\
\hline nomenclaturalCode & $\begin{array}{l}\text { The nomenclatural code (or codes in the case of an ambiregnal name) under } \\
\text { which the scientificName is constructed. A constant ("International Code of } \\
\text { Nomenclature for algae, fungi and plants"). }\end{array}$ \\
\hline taxonomicStatus & $\begin{array}{l}\text { The status of the use of the scientificName as a label for a taxon. A constant } \\
\text { ("accepted"). The taxonomy is linked to a checklist dataset (https://doi.org/ } \\
10.15468 / 7 \mathrm{zk} 2 \mathrm{y} 5 \text { ) that defines the concept. }\end{array}$ \\
\hline
\end{tabular}

\section{Acknowledgements}

The field data were collected within the framework of MSU state assignment number 121032500089-1. The data processing and text writing were supported by the Russian Foundation for Basic Research under Grant number 19-04-00799a.

We are grateful to the administration and staff of Central Forest State Nature Biosphere Reserve for supporting our fieldwork and personally thank Dr. Anatoly Zheltukhin, Deputy Director for Science of the Nature Reserve, for his help and advice. We thank Valentina 
Borodulina, Veronika Gorik and Maria Nosova for their help in the fieldwork, Mikhail Kozhin for his help with the dataset preparation and Alexey Seregin for the dataset publication. We are grateful to the reviewers for their detailed recommendations that allowed us to substantially improve our manuscript.

\section{Author contributions}

Oxana Cherednichenko - fieldwork, species identification, dataset compilation, manuscript preparation. Tatiana Gavrilova - dataset preparation, manuscript preparation.

\section{References}

- $\quad$ Bardunov L, Novikov V (Eds) (2008) Red Data Book of the Russian Federation (Plants and Fungi). KMK Scientific Press, Moscow, 855 pp. [In Russian]. [ISBN 958-5-87317-476-8]

- Cherednichenko O, Borodulina V (2018) Biodiversity of herbaceous vegetaton in abandoned and managed sites under protection regime: a case study in the Central Forest Reserve, NW Russia. Hacquetia 17 (1): 35-59. [In English]. https://doi.org/ 10.1515/hacq-2017-0015

- $\quad$ Cherednichenko OV (2021) Vascular plants of grasslands in Central Forest Nature Reserve (Tver Oblast, Russia). Lomonosov Moscow State University. Release date: 2021-10-13. URL: https://doi.org/10.15468/ufbxsn

- $\quad$ Cherednichenko OV, Gavrilova TM, Borodulina VP, Zhelezova SD, Elumeeva TG (2021) Structure of aboveground phytomass of abandoned and managed mesic meadows in the forest zone: a case study from the Central Forest Reserve, Russia. Botany Letters 168 (2): 297-309. [In English]. https://doi.org/10.1080/23818107.2021.1884899

- Chytrý M, Otýpková Z (2003) Plot sizes used for phytosociological sampling of European vegetation. Journal of Vegetation Science 14 (4): 563-570. https://doi.org/ 10.1111/j.1654-1103.2003.tb02183.x

- $\quad$ Elumeeva T, Zhelezova S, Cherednichenko O (2017) Leaf area of meadow plants under regimes of mowing and protection in the Central Forest Reserve. Bulletin of Bryansk Department of Russian Botanical Society 39-42. https://doi.org/10.22281/23074353-2017-4-39-42

- $\quad$ Elumeeva TG, Cherednichenko OV, Gavrilova TM (2021) Stabilization and decomposition rate of standard material in herbaceous communities of the forest zone. Ekosistemy 25: 12-21. https://doi.org/10.37279/2414-4738-2021-25-12-21

- Karpov VG (Ed.) (1983) Факторы регуляции экосистем еловых лесов. [Regulation factors of spruce forest ecosystems]. Nauka Leningradian Branch, Leningrad, 318 pp. [In Russian].

- Konechnaya GY (2012) The vascular plants of Central Forest Nature Reserve: Annotated list of species. RAS Committee on Biodiversity Conservation, Moscow, 75 pp. [In Russian]. [ISBN 978-5-350-00269-0]

- Korablev AP, Kessel DS, Pukinskaia MY, Schukina KV, Volkov VP (2018) Drivers of field layers composition in nemoral spruce forests (Picea abies L.) of Central-Forest Nature 
Reserve. Vestnik Tverskogo Gosudarstvennogo Universiteta. Seriya: Biologiya i Ekologiya (4)118-125. [In Russian]. https://doi.org/10.26456/vtbio32

- Kurayeva EN, Minayeva TY, Shaposhnikov ES (1999) Typological structure and floristic diversity of forest communities. In: Smirnova OV, Shaposhnikov ES (Eds) Forest successions in protected areas of Russia and problems of biodiversity conservation. Russian Botanical Society, St. Petersburg, 314-323 pp. [In Russian]. [ISBN 5-86871-030-4].

- Maevsky PF (2014) Флора средней полосы европейской части России. [Flora of Middle Part of European Russia]. 11th ed. KMK Scientific Press, Moscow, 635 pp. [In Russian]. [ISBN 978-5-87317-958-9]

- Minaeva TY, Glushkov IV, Nosova MB, Starodubtseva OA, Kuraeva EN, Volkova EM (2007) Report on the bogs of the Central Forest Reserve. In: Zheltukhin AS (Ed.) Integrated studies in the Central-Forest State Nature Biosphere Reserve: Their Past, Present and Future. 30 pp. [In Russian].

- Minaeva TY (2010) The peculiarities of seed reproduction biology of some species of monocotyledonous peatland plant species. Botanicheskiy Zhurnal 95 (4): 482-495. [In Russian].

- Minayeva TY, Shaposhnikov ES (1999) Characteristic of the region and nature conditions of the Nature Reserve territory. In: Smirnova OV, Shaposhnikov ES (Eds) Forest successions in protected areas of Russia and problems of biodiversity conservation. Russian Botanical Society, St. Petersburg, 296-299 pp. [In Russian].

- Minayev NA, Konechnaya GY (1976) The flora of Central Forest Nature Reserve. Nauka, Leningrad, 104 pp. [In Russian].

- Mirkin BM, Naumova LG (2012) The current state of the basic concepts in Vegetation Science. Gilem, Ufa, 488 pp. [In Russian].

- Notov AA (2005) Materials for the flora of Tver Oblast. Part 1: Higher plants. 4th edition, revised and supplement. Gers, Tver, 214 pp. [In Russian].

- $\quad$ Orlov SV, Sokolov DL, et al. (Eds) (2016) Red Data Book of Tver Oblast. 2. Tverskoy Pechatnyi Dvor, Tver, 400 pp. [In Russian].

- Safronova IN, Yurkovskaya TK, Miklyaeva IM, Ogureeva GN (2010) Zones and altitudinal zonality types of vegetation of Russia and adjacent territories. In: Talbot S, Charron T, Barry T (Eds) Proceedings of the Fifth International Workshop: Conservation of Arctic Flora and Fauna (CAFF). Flora Group., 21. Circumboreal Vegetation Mapping (CBVM) Workshop, Helsinki, Finland, November 3-6th, 2008. CAFF International Secretariat, CAFF Flora Expert Group (CFG), Helsinki, 52-74 pp. [In English]. URL: https://oaarchive.arctic-council.org/bitstream/handle/11374/247/CFG CBVM Proceedings_Helsinki_Finland_Nov_2008\%20\%281\%29.pdf?sequence=1\&isAllowed=y

- Shuyskaya EA (2018) Protected vascular plant species of the Central Forest Reserve. Contribution of specially protected natural areas to the ecological sustainability of regions: Current state and prospects, Federal State Budgetary Institution Kologrivski Forest Nature Reserve named after MG Sinitsyn, September 20-21 2018. 98-104 pp. [In Russian].

- Tsvelev NN (2000) Определитель сосудистых растений северо-западной России (Ленинградская, Псковская и Новгородская области). [Key to vascular plants of northwestern Russia (Leningrad, Pskov and Novgorod regions)]. SPCPA Publishing House, Saint Petersburg, 781 pp. [In Russian]. 
- Vinogradova YK, Majorov SR, Notov AA (2011) The "Black Book" of the flora of Tver Oblast: Alien plant species in the ecosystems of Tver Oblast. KMK Scientific Press Ltd., Moscow, 292 pp. [In Russian].

- Zorina AA, Shuyskaya EA, Kurakina IV, Volkov VP, Ogurtsov SS, Stepanov SN (2020) Climatic causes of plant flowering time displacement in the Central Forest Reserve. Povolzhskiy Journal of Ecology 1: 52-65. https://doi.org/10.35885/1684-7318-2020$\underline{1-52-65}$ 